\title{
10 \\ A nodal perspective of governance: Advances in nodal governance thinking
}

\section{Cameron Holley and Clifford Shearing ${ }^{1}$}

For centuries, regulatory thinking has been inspired by the powerful story of a benign giant, made up of the bodies of people, beautifully depicted in the frontispiece by Abraham Bosse, with input by Thomas Hobbes for his Leviathan, published in 1651 (Hobbes 1951). This giant stands over a landscape that he rules on behalf of these people. In his left hand, he carries a crosier that symbolises his legitimacy as a ruler. In his right is a sword that symbolises his ability to overcome resistance to his rule. This great leviathan-whose contemporary incarnation is the nation-state-was conceived as being so powerful that he would be able to shape the wills of 'his' people in ways that would ensure peace at home as well as aid against enemies abroad. This story, told with much acumen by Hobbes, has provided an influential and compelling way of thinking about and creating arrangements for governance in the West (Burris et al. 2005)—in particular, the governance of security through the institutions of criminal justice.

1 This work is, in part, based on research supported by the South African National Research Foundation (NRF), an Australian Research Council (ARC) Discovery Early Career Researcher Award (DE140101216) and an ARC Linkage Grant (LP130100967). Any opinions, findings, conclusions or recommendations expressed in this material are those of the authors and the NRF does not accept any liability in this regard. 
The contours of this story have, at different times and places, taken different shapes (Braithwaite 1999), from Weber's (1946) 'human community', which claims a monopoly of the legitimate use of physical force within a given territory, to the minimalist nightwatchmen state (Nozick 1974) and the more active welfare state associated with Keynesian thinking (Keynes 1933). Despite their differences, these stories all embrace a unified vision of governance that was nicely captured within the terms of the Peace of Westphalia of 1648, in which the parties to this treaty conceived of sovereign states as enjoying exclusive authority within their geographic regions (Krasna 2001; Shearing and Johnston 2010).

Although modern versions of this vision have long dominated governance thinking, this persuasive image has never constituted a satisfactory empirical account of the realities of governance. Scott (2009) draws attention to this in his historical study of the 2,000-year history of the hill-people of Zomia in South-East Asia, who have deliberately and consistently strategically organised themselves to keep the state at arm's length. This more polycentric view of governance has been confirmed by a host of other studies within political science and criminology (see, for example, Rhodes 2007; Brodeur 2010; Dupont 2004). Criminology and related discussions of 'crime control' have long noted the presence of both public and private 'auspices' and 'providers' (Bayley and Shearing 2001) as well as the role of non-human 'actants' (Latour 2013)—for example, Shearing and Stenning's (1984) analysis of the governance of security within Disneyworld and Lessig's (1999) analysis of the regulation of cyberspace.

A variety of decentred theories of governance has been developed to capture this reality of governance beyond the state (see, for example, Castells 2000; Black 2002; Rhodes 2007; Ostrom 2010; Bisschop and Verhage 2012). These theories do recognise explorations of state-focused forms of 'command and control' governance that often involve coercion exercised through hierarchy. However, they have also told an alternative story of governance as having multiple sources and many forms that appreciate, to use Foucaultian language, that: 'Power is everywhere; not because it embraces everything, but because it comes from everywhere' (Foucault 1984: 93).

While some of these stories of decentred or polycentric governance (Ostrom 2010) have focused on 'flows' and 'networks' (Castells 2000), others have focused attention on nodes as sites of governance and have recognised the possibility of Robinson Crusoe nodes that can and do 
operate in relative isolation from other sites (Burris et al. 2005). In this understanding, nodes - as 'auspices' and 'providers' of governance (Bayley and Shearing 2001) — are understood not simply as points established by the intersection of flows within networks (Castells 2000: 15-16,22), but rather as sites of capacity, knowledge and resources relevant to 'shaping the flow of events', to use Parker and Braithwaite's (2003: 119) simple and succinct definition of governance.

In developing this perspective, Wood and Shearing (2007: 149) define nodes as follows:

Governing nodes are organisational sites (institutional settings that bring together and harness ways of thinking and acting) where attempts are made to intentionally shape the flow of events. Nodes govern under a variety of circumstances, operate in a variety of ways, are subject to a variety of objectives and concerns, and engage in a variety of different actions to shape the flow of events. Nodes relate to one another, and attempt to mobilise and resist one another, in a variety of ways so as to shape matters in ways that promote their objectives and concerns. Nodal governance is diverse and complex.

Within this decentred conception of governance, there are multiple 'tops' and many 'downs' and they 'overlap' (Wood and Shearing 2007: 149). In Brodeur's (2006: ix) terms, the pluralisation of security 'does away with the single stuff mythology' (for discussion of boundaries within complex systems, see Cilliers 2005).

Within political science this emerging 'governance perspective' (Rhodes 2007) conceives of governance as extending beyond government in much the same way as policing, within criminology, has come to be understood as extending beyond police (Brodeur 2010). Explorations of nodal governance and networked governance have become increasingly commonplace. Within this polycentric perspective, while states are recognised as significant governors, they are conceived of as existing in a broader context of other auspices and providers of governance.

This conception considers the questions of who governs and how they govern as issues that cannot be determined a priori, but that require careful exploration through empirical and context-specific research. Johnston and Shearing (2003: 22-30) have developed an eight-point framework to be used in guiding such explorations (for an example of its use, see Kerr 2015). Crucial to the empirical inquiries that this polycentric conception of governance has generated have been the issues of how 
different auspices and providers of governance relate to one another and how, and when, they enrol the capacities and resources of others as they seek to realise their governance objectives (Nakueira 2014).

These empirical 'post-Foucauldian' (McKee 2009) inquiries into 'multilateral' (Bayley and Shearing 2001) or 'multidimensional' (Rhodes 2007) forms of governance (for a recent example, see Kerr 2015) are to be distinguished from the normative arguments of political philosophy that consider who should govern, how they should govern and to whom they should be accountable (for a discussion, see McLaughlin 2007: Chapter 4). Within the context of nodal systems of governance, these normative explorations often argue that, for governance to be legitimate, it should, in Loader and Walker's (2007) terms, be 'state-anchored'. That is, governance, it is argued, should, if it is to be legitimate, be both overseen and authorised by states who are themselves authorised, via legitimate political processes, to govern. ${ }^{2}$

Many differing policy advocates have employed and developed the normative position that governance should be overseen and authorised by states. For instance, Osborne and Gaebler (1993) have drawn specifically on the normative thinking of economists such as Frederick Hayek $(1945,2007)$ and Milton Friedman (1962) to support 'neoliberal' governance arrangements organised around the outsourcing of the provision of governance by the state to private and civil-sector nodes. This issue of how 'plurality needs to be managed and whether, in fact, it needs to be' (Kerr 2015: 26) is a significant topic of discussion and debate within nodal governance (see, for example, Bayley and Shearing 1996; Ayling et al. 2009).

Much exploration of nodal forms of governance took place at the Regulatory Institutions Network (RegNet), including work at The Australian National University (ANU) before RegNet came into existence (Grabosky et al. 1993). Several scholars based at RegNet have made important strides in developing polycentric understandings of governance-for example, Julie Ayling, John Braithwaite, Val Braithwaite, Peter Drahos, Peter Grabosky, Neil Gunningham, Monique Marks and Jennifer Wood (see also Holley, Chapter 42, this volume). One of the most recent of these has been Russell Brewer's

2 For a discussion of the practical implications of 'anchored pluralism' (Loader and Walker 2006: 194), see Ayling et al. (2009); and for a comparison of nodal governance and anchored pluralism, see White (2011: 90-5). 
(2014) work on the governance of security within waterfronts and his chapter in this volume (see Chapter 26) that analyses patterns of connections within security networks.

While much of the research exploring nodal ordering has taken place within criminology - work that uses a polycentric nodal framing both explicitly and implicitly ${ }^{3}$-increasingly, the nodal governance idea is being developed and explored by scholars within other areas. ${ }^{4}$

Nodal governance thinking has to date been centred primarily on the twin concepts of nodes and networks. Both concepts are grounded in a constitutive understanding (Shearing 1993) that sees governance as layered. In this understanding, worlds that present themselves as given are understood as being constituted through subterranean governing processes that have shaped events to produce these worlds.

Coordination between nodes is made possible via networks. When this happens, governance becomes the property of networks rather than ... the product of any single centre of action' (Johnston and Shearing 2003: 148); under these conditions, governance is said to be 'coproduced' and collaborative (Holley et al. 2012). Crawford (2006: 466) writes of networks linking nodes into 'horizontal partnerships' with a presupposed 'element of coordination'. In reflecting on such arrangements, Johnston and Shearing (2003) insist that, within networks, there is no necessity for a single locus of control. Nor, they argue, do nodes within networks necessarily work together to promote shared outcomes. Furthermore, who does what within these networks can, and does, change across space and over time. Certainly, some nodes can be fixed and wield power by regulating other nodes (Burris et al. 2005). In such cases, networks will often need to enrol these nodes to 'capture' their power or their access to other nodal networks (Drahos 2004). Even so, networks are very often fluid and rarely fixed. In the words of Wood and Dupont (2006: 4), networks and the nodal assemblages constitute 'temporary hubs of practices' involving iterative processes carried out by a range of actors who occupy different positions of influence. Networks may exist within and across sectors such as environment, policing, health or other regulatory issues (Wright and Head 2009).

3 See, for example, Ericson and Doyle's (2004) groundbreaking work on insurance and Pat O'Malley's (2010) work on risk.

4 See, for example, Burris (2004) and his research on public health and Peter Drahos and John Braithwaite's (2002) work on developments within intellectual property issues. 
Nodes are regarded as 'any formal or informal institution that is able to secure at least a toe-hold in a governance network' (Burris et al. 2008: 25). For Braithwaite (2008), nodes are what make governance 'buzz'. While nodes, like networks, are typically not fixed, they are nonetheless conceived of as 'point [s] in time and space'(Braithwaite 2004:312), where actors mobilise pooled resources to tie together strands in networks of power. They may comprise individuals, groups (or parts of groups), organisations (or parts of organisations) or states (or parts thereof); they may be large or small, tightly or loosely connected and inclusive or exclusive; they may engage in similar activities or they may be specialised (Shearing and Johnston 2010). Nodes can function separately or jointly as sponsors of governmental actions and/or as providers who supply governmental services such as security (Shearing and Wood 2003).

Consistent with a constitutive conception of governance, the boundaries of networks, and the nodes within them, are not a given. They may be defined with clear boundaries or their boundaries may be blurred; organisationally, they may be decentralised or hierarchical. While nodes and networks are constantly reconstituting themselves to form new structures, nodes typically do too much planning for their governing activities to be considered purely spontaneous in a Hayekian sense (Baumgartner and Pahl-Wostl 2013). Indeed, with such flux-and with neither the state nor any other set of nodes given conceptual priorityunderstanding how certain nodes plan and interact with other nodes, and then form assemblages and networks, requires considerable research (Shearing and Wood 2003).

Such an empirical analysis, it is argued, requires the investigation of four principal elements: mentalities (relating to how nodes think about a governance outcome-for example, security, or a safe environment); technologies (relating to the methods they might use to facilitate it); resources (relating to the social, cultural, economic or other means they might deploy in its furtherance); and institutions (relating to the structures that enable the mobilisation of resources, mentalities and technologies in pursuit of governance outcome) (Johnston and Shearing 2003; Burris et al. 2005). Mapping these elements typically requires the compilation of data by a variety of means, including documentary analysis, observation, qualitative interviews and focus groups, as well as the quantitative techniques that currently dominate network analysis. In particular, ethnographic methods are used to deepen more quantitative analyses (Shearing and Johnston 2010). In accord with the constitutive 
conception noted earlier, nodal governance recognises that every 'world' is 'a human invention and reinvention' (Johnston and Shearing 2003: 148) that is accomplished through governing processes.

The nodal governance framework has been used by a variety of scholars to shape and guide their analyses of governance processes. A good example of this is John Braithwaite's (2008) insightful discussion of TimorLeste, where he uses nodal governance thinking in conjunction with a responsive regulation framework to map and understand post-conflict security governance. He considers how the governance of security within this context involves a variety of nodes, each with access to different sets of resources, authority and mentalities, each of which engages the other in realising security agendas.

Particularly valuable in this exploration is the way Braithwaite enhances nodal governance thinking by including 'things' as 'actants' (Latour 2004) as he explores the resources that nodal agents deploy as they seek to shape the flow of events. In this analysis, he contrasts the way in which two public sector nodes (the Australian Federal Police and the Guarda Nacional Republicana from Portugal) brought to the governance of security in Timor-Leste very different governing sensibilities.

While Braithwaite's focus is principally on formal nodes, James Martin (2012), in contrast, focuses his attention on nodes within the informal sector. He draws on Dupont's (2004) integration of Bourdieu's (1986) notion of a variety of 'capitals' to explore the mentalities and resources of nodal action. In particular, he explores the way in which 'force capital' is used in exercising control over physical spaces.

A third example of the systematic use of a nodal conception to explore security governance is provided by John Kerr (2015), who uses the analytical framework for nodal mapping developed by Johnston and Shearing (2003) to explore the complex set of public, private and civil arrangements involved in the coproduction of 'art security'. As is common across nodal analyses, Kerr focuses on the ways in which nodes attempt to enrol others to achieve their governing objectives.

Peter Drahos, in his work on the governance of intellectual property, has also utilised a nodal analysis to explore 'nodal concentrations of power and knowledge' (Drahos 2005: 21). Drahos utilises a nodal framing and enhances it with his analysis of what he terms superstructural nodes: 'Super-structural nodes are the command 
centers of networked governance' (2004: 405). Yet another example, at the boundary of established security governance, is the use of a nodal governance framework to explore normative 'good governance' agendas within public health (see, for example, Burris et al. 2007). For Burris (2004), a nodal analysis is useful in finding innovative institutional arrangements for the delivery of key social goods.

One strength of the nodal approach, as applied by these and many other authors, is that it reveals the complexity of governing processes while at the same time opening up new avenues for explanatory and normative thinking. As Wright and Head (2009: 207) note: 'The potential strength of such models could be their ability to map interactions and capacities of nodes, both as sites of continuity and of contestation.'

Nodal analysis opens up opportunities for first describing, and then transforming, networked relations that produce governance outcomes. As Johnston and Shearing (2003: 160) write, in drawing attention to the normative implications of nodal thinking:

Our point is merely that with demonstrable evidence of nodal governance becoming more and more apparent, opportunities may arise to transform networked relations in ways that could, under the right conditions, advance just and democratic outcomes.

Braithwaite (2004), in discussing 'methods of power', suggests how global governance processes might be reshaped through reshaping nodal relations (see also Ayling et al. 2009). As Braithwaite (2004: 330) explains, 'weak actors, wielding only puny sanctions, can escalate to enrolling more and more actors of increasingly greater clout to a project of network confrontation with the strong'.

Given the history of nodal governance thinking, many of the scholars who have used it have done so within the fields of policing and security, and it is here that much of the debate over its value as an analytical framework has taken place. Within this context, nodal governance thinking has been deployed to explore the 'pluralisation' (Loader 2000) of security provision through private, community, public and hybrid forms of providers; the role of voluntary service agencies (Martin 2012; Huey 2008); and the development of 'mass private property' (Shearing and Stenning 1981) in the form of shopping malls, gated communities and the like (Wakefield 2003). 
A number of scholars have questioned what they regard as the tendency of a nodal framework-given its history as an alternative to statecentred analytical frameworks- to neglect vertical relations in favour of horizontal ones. Kerr (2015: 159) draws attention to this when he writes that:

Although it is necessary to avoid state fetishism (Shearing 2006) when analysing art security in London, it is also important to eschew private fetishism because of the huge amount of art in London for which the public sector takes responsibility and the manner in which public and private nodes work together (even if only temporarily).

In a similar vein, Cook (2010: 456) has argued that:

[S]tudies of nodal governance suffer from excessive localism inasmuch as they almost always focus on 'horizontal' networks, ignoring the more 'vertical' connections to actors and institutions that operate at other spatial scales.

These critiques echo concerns expressed by Loader and Walker (2007; see also Boutellier and van Steden 2011) that nodal governance thinkers are inclined to treat states as 'idiots' and, in so doing, have lost sight of the important role states play in 'civilising' governance processes.

This critique is also taken up by Crawford and Lister (2004), who argue that the state should be conceived of as more than merely one node among many, as the role of states remains pivotal in respect of both symbolic power and its regulatory capacity. According to this line of critique, nodal governance thinking runs the risk of unintentionally weakening state institutions and ceding legitimacy to nodes of uncertain virtue (Wright and Head 2009). Similarly, Zedner (2009: 161) notes that, instead of being part of the solution, the emphasis that some nodal thinkers place on empowering communities may encourage vigilantism, the pursuit of private vengeance and the vilification of particular groups of individuals. In the view of these scholars, nodal governance's decentring of states, and what is interpreted to be a denial of the need for strong state institutions, is regarded as unwise for both explanatory and normative reasons. By emphasising the plural locations of power and legitimacy, so the argument goes, nodal governance thinking risks denying the need for strong state institutions and ceding influence to nodes of uncertain legitimacy (Wright and Head 2009). Even so, there is still much work to be done to resolve such debates. For instance, as Drahos's (2010) work on patent office governance has 
shown, thinking in a nodal manner can in fact strengthen weak developing states' patent offices, which can compete with multinationals only when they enrol outside actors to help with the examination of patents, and thus increase their legitimacy.

Other scholars have used their critiques to shift terminologiesfor example, Brodeur (2010), with his notion of 'the policing web', Abrahamsen and William's (2011) use of the idea of 'security assemblages' and Baker's (2007) notion of 'multi-choice policing'. Others have sought to expand on the range of nodes that nodal governance recognises (for example, Brewer 2014, in his study of waterfronts). Yet other scholars have sought to recognise other theoretical possibilities-for example, Drahos (2004), with his notion of 'superstructural nodes'. Still others have sought to extend the normative repertoire of nodal governance thinking. Marks and Wood (2010), for example, use the 'minimalist and minimal police perspective' in seeking to extend previous explanatory and normative accounts of nodal governance.

While policing and the policing arena have been the principal empirical terrain of nodal governance thinking, this terrain is now broadening. In the environmental area, for instance, there has been growing use of the nodal governance framework (Holley et al. 2012). Similarly, Baumgartner and Pahl-Wostl (2013) have used a nodal governance theoretical framework to study global water governance, while Burris and his collaborators have used a nodal governance framework within public health (see, for example, Burris 2004; Burris et al. 2007). Within a security umbrella, nodal governance thinking has been applied to harbours and port security (van Sluis et al. 2012; Brewer 2014), the security of taxi drivers (Paes-Machado and Nascimento 2014) and child protection (Harris and Wood 2008). Another area of expansion of nodal thinking has been in relation to the governance of cyberspace (Wall 2007; Huey et al. 2013; Nhan 2010).

In conclusion, the nodal governance perspective has done much to encourage an emerging body of empirical research, across a range of different social contexts, which has explored the shifting shape of policing and security governance, as well as an increasingly wide variety of public problems, including the environment, health and intellectual property. While nodal governance may 'lack' a normative model, it provides a valuable means for describing the dynamics and structures of regulatory networks including non-state actors. Its fundamental benefit, 
then, is its capacity to open space for new normative responses otherwise closed to traditional state-centric governance perceptions (Wright and Head 2009).

\section{Further reading}

Braithwaite, J 2000. 'The new regulatory state and the transformation of criminology', British Journal of Criminology 40(2): 222-38. doi. org/10.1093/bjc/40.2.222.

Braithwaite, J, Charlesworth, HC and Soares, A 2012. Networked Governance of Freedom and Tyranny: Peace in Timor-Leste. Canberra: ANU E Press.

Froestad, J, Grimwood, S, Herbstein, T and Shearing, C 2015. 'Policy design and nodal governance: A comparative analysis of determinants of environmental policy change in a South African city', Journal of Comparative Policy Analysis: Research and Practice 17(2): 174-91. doi.org/10.1080/13876988.2013.823756.

\section{References}

Abrahamsen, R and Williams, M 2011. Security Beyond the State: Private Security in International Politics. Cambridge: Cambridge University Press.

Ayling, J, Grabosky, P and Shearing, C 2009. Lengthening the Arm of the Law: Enhancing Police Resources in the Twenty-first Century. Cambridge: Cambridge University Press.

Baker, B 2007. Multi-choice Policing in Africa. Uppsala, Sweden: Nordiska Afrikainstitutet.

Baumgartner, T and Pahl-Wostl, C 2013. 'UN-Water and its role in global water governance', Ecology and Society 18(3): art. 3. doi. org/10.5751/ES-05564-180303.

Bayley, DH and Shearing, CD 1996. 'The future of policing', Law and Society Review 30(3): 585-606. doi.org/10.2307/3054129. 
Bayley, DH and Shearing, CD 2001. The New Structure of Policing: Description, Conceptualization, and Research Agenda. Washington, DC: National Institute of Justice.

Bisschop, L and Verhage, A 2012. 'The complex(ity) of policing dirty crime', Politie Studies: Tides E Currents of Policing 25: 273-90.

Black, J 2002. 'Critical reflections on regulation', Australian Journal of Legal Philosophy 27: 1-35.

Bourdieu, P 1986. 'The forms of capital', in J Richardson (ed.), Handbook of Theory and Research for the Sociology of Education. New York: Greenwood, pp. 241-58.

Boutellier, H and van Steden, R 2011. 'Governing nodal governance: The "anchoring" of local security networks', in A Crawford (ed.), International and Comparative Criminal Justice and Urban Governance: Convergences and Divergences in Global, National and Local Settings. Cambridge: Cambridge University Press, pp. 461-82. doi.org/10.1017/CBO9780511974953.018.

Braithwaite, J 1999. 'Accountability and governance under the new regulatory state', Australian Journal of Public Administration 58(1): 90-7. doi.org/10.1111/1467-8500.00077.

Braithwaite, J 2004. 'Methods of power for development: Weapons of the weak, weapons of the strong', Michigan Journal of International Law 26: 297-330.

Braithwaite, J 2008. Regulatory Capitalism: How it Works, Ideas for Making it Work Better. Cheltenham, UK: Edward Elgar. doi. org/10.4337/9781848441262.

Brewer, R 2014. Policing the Waterfront: Networks, Partnerships, and the Governance of Port Security. Oxford: Oxford University Press. doi. org/10.1093/acprof:oso/9780199687367.001.0001.

Brodeur, JP 2006. 'Foreword', in J Wood and B Dupont (eds), Democracy, Society and the Governance of Security. Cambridge: Cambridge University Press, pp. xi-x. doi.org/10.1017/CBO97805 11489358.001.

Brodeur, JP 2010. The Policing Web. Oxford: Oxford University Press. doi.org/10.1093/acprof:oso/9780199740598.001.0001. 
Burris, S 2004. 'Governance, microgovernance and health', Temple Law Review 77(2): 335-61.

Burris, S, Drahos, P and Shearing, C 2005. 'Nodal governance', Australian Journal of Legal Philosophy 30: 30-58.

Burris, S, Hancock, T, Lin, V and Herzog, A 2007. 'Emerging strategies for healthy urban governance', Journal of Urban Health: Bulletin of the New York Academy of Medicine 84(Supp. 1): i154-63.

Burris, S, Kempa, M and Shearing, C 2008. 'Changes in governance: A cross-disciplinary review of current scholarship', Akron Law Review 41(1): 1-67.

Castells, M 2000. 'Materials for an exploratory theory of the network society', The British Journal of Sociology 51(1): 5-24. doi. org/10.1080/000713100358408.

Cilliers, P 2005. 'Knowledge, limits and boundaries', Futures 37(7): 605-13. doi.org/10.1016/j.futures.2004.11.001.

Cook, IR 2010. 'Policing, partnerships, and profits: The operations of business improvement districts and town center management schemes in England', Urban Geography 31(4): 453-78. doi.org/10.2747/02723638.31.4.453.

Crawford, A 2006. 'Networked governance and the post-regulatory state?: Steering, rowing and anchoring the provision of policing and security', Theoretical Criminology 10(4): 449-79. doi. org/10.1177/1362480606068874.

Crawford, A and Lister, S 2004. 'The patchwork shape of reassurance policing in England and Wales', Policing 27(3): 413-30. doi. org/10.1108/13639510410553149.

Drahos, P 2004. 'Intellectual property and pharmaceutical markets: A nodal governance approach', Temple Law Review 77: 401-24.

Drahos, P 2005. 'An alternative framework for the global regulation of intellectual property rights', Austrian Journal of Development Studies (1). 
Drahos, P 2010. The Global Governance of Knowledge: Patent Offices and their Clients. Cambridge: Cambridge University Press. doi. org/10.1017/CBO9780511676581.

Drahos, P and Braithwaite, J 2002. Information Feudalism: Who Owns the Knowledge Economy. London: Earthscan.

Dupont, B 2004. 'Security in the age of networks', Policing and Society: An International Journal of Research and Policy 14(1): 76-91. doi.org/ 10.1080/1043946042000181575.

Ericson, R and Doyle, A 2004. Uncertain Business: Risk, Insurance and the Limits of Knowledge. Toronto: University of Toronto Press.

Foucault, M 1984. The History of Sexuality. Volume 1: An Introduction. Harmondsworth, UK: Penguin.

Friedman, M 1962. Capitalism and Freedom. Chicago: University of Chicago Press.

Grabosky, P, Shearing, C and Braithwaite, J 1993. 'Introduction', in P Grabosky and J Braithwaite (eds), Business Regulation and Australia's Future. Canberra: Australian Institute of Criminology, pp. 1-8.

Harris, N and Wood, J 2008. 'Governing beyond command and control: A responsive and nodal approach to child protection', in M Deflem (ed.), Surveillance and Governance: Crime Control and Beyond, Sociology of Crime, Law and Deviance. Bingley, UK: Emerald Group, pp. 32744. doi.org/10.1016/S1521-6136(07)00215-1.

Hayek, FA 1945. The Constitution of Liberty. Chicago: University of Chicago Press.

Hayek, FA 2007. 'The use of knowledge in society', The American Economic Review 35(4): 519-30.

Hobbes, T 1951. Leviathan. CB Macpherson, ed. London: Penguin.

Holley, C, Gunningham, N and Shearing, C 2012. The New Environmental

Governance. London: Earthscan. 
Huey, L 2008. "When it comes to violence in my place, I am the police!" Exploring the policing functions of service providers in Edinburgh's Cowgate and Grassmarket', Policing and Society: An International Journal of Research and Policy 18(3): 207-24. doi. org/10.1080/10439460802008751.

Huey, L, Nhan, J and Broll, R 2013. "Uppity civilians" and "cyber vigilantes": The role of the general public in policing cybercrime', Criminology and Criminal Justice 13(1): 81-97. doi.org/ 10.1177/1748895812448086.

Johnston, L and Shearing, C 2003. Governing Security Explorations in Policing and Justice. London: Routledge.

Kerr, J 2015. Securitization and Policing of Art Theft: The Case of London. London: Ashgate.

Keynes, JM 1933. The Means to Prosperity. London: Macmillan \& Co.

Krasna, S 2001. Problematic Sovereignty: Contested Rules and Political Possibilities. New York: Columbia University Press. doi.org/10.7312/ kras12178.

Latour, B 2004. Politics of Nature: How to Bring the Sciences into Democracy. Cambridge, Mass.: Harvard University Press.

Latour, B 2013. Facing Gaia: Six lectures on the political theology of nature, Gifford Lectures on Natural Religion, Edinburgh, 18-28 February.

Lessig, L 1999. Code and Other Laws of Cyberspace. New York: Basic Books.

Loader, I 2000. 'Plural policing and democratic governance', Social \& Legal Studies 9(3): 323-45. doi.org/10.1177/ 096466390000900301.

Loader, I and Walker, N 2006. 'Necessary virtues: The legitimate place of the state in the production of security', in J Wood and B Dupont (eds), Democracy, Society and the Governance of Security. Cambridge: Cambridge University Press, pp. 165-95. doi.org/10.1017/ CBO9780511489358.009. 
Loader, I and Walker, N 2007. Civilizing Security. Cambridge: Cambridge University Press. doi.org/10.1017/CBO9780511611117.

McKee, K 2009. 'Post-Foucauldian governmentality: What does it offer critical social policy analysis?', Critical Social Policy 29(3): 465-86. doi.org/10.1177/0261018309105180.

McLaughlin, E 2007. The New Policing. London: Sage Publications.

Marks, M and Wood, J 2010. 'South African policing at a crossroads: The case for a "minimal" and "minimalist" public police', Theoretical Criminology 14(3): 311-29. doi.org/10.1177/1362480610369785.

Martin, J 2012. 'Informal security nodes and force capital', Policing and Society: An International Journal of Research and Policy 23(3): 1-19.

Nakueira, S 2014. New architectures of governance: Transnational private actors, enrolment strategies and the security governance of sports mega events, $\mathrm{PhD}$ dissertation, University of Cape Town, Cape Town.

Nhan, J 2010. Policing Cyberspace: A Structural and Cultural Analysis. El Paso, Tex.: LFB Scholarly.

Nozick, R 1974. Anarchy, State and Utopia. New York: Basic Books.

O'Malley, P 2010. 'Simulated justice: Risk, money and telemetric policing', British Journal of Criminology 50(5): 795-807. doi. org/10.1093/bjc/azq036.

Osborne, D and Gaebler, T 1993. Inventing Government: How the Entrepreneurial Spirit is Transforming the Public Sector. New York: Plume.

Ostrom, E 2010. 'Beyond markets and states: Polycentric governance of complex economic systems', American Economic Review 100(3): 641-72. doi.org/10.1257/aer.100.3.641.

Paes-Machado, E and Nascimento, AM 2014. 'Conducting danger: Practices and nodal networks of security governance among taxi drivers', International Journal of Comparative and Applied Criminal Justice 38(1): 1-22. doi.org/10.1080/01924036.2013.848220. 
Parker, C and Braithwaite, J 2003. 'Regulation', in P Cane and M Tushnet (eds), The Oxford Handbook of Legal Studies. Oxford: Oxford University Press, pp. 119-45.

Rhodes, RA 2007. 'Understanding governance: Ten years on', Organization Studies 28(8): 1243-64. doi.org/10.1177/ 0170840607076586.

Scott, JC 2009. The Art of Not Being Governed. New Haven, Conn.: Yale University Press.

Shearing, C 1993.'A constitutive conception of regulation', in P Grabosky and J Braithwaite (eds), Business Regulation and Australia's Future. Canberra: Australian Institute of Criminology, pp. 67-80.

Shearing, C 2006. 'Reflections on the refusal to acknowledge private governments', in J Wood and B Dupont (eds), Democracy, Society and the Governance of Security. Cambridge: Cambridge University Press, pp. 11-32. doi.org/10.1017/CBO9780511489358.003.

Shearing, C and Johnston, L 2010. 'Nodal wars and network fallacies: A genealogical analysis of global insecurities', Theoretical Criminology 14(4): 495-514. doi.org/10.1177/1362480610378828.

Shearing, C and Stenning, PC 1981. 'Modern private security: Its growth and implications', Crime and Justice 3: 193-245. doi. org/10.1086/449080.

Shearing, C and Stenning, PC 1984. 'From the Panopticon to Disney World: The development of discipline', in A Doob and E Greenspan (eds), Perspectives in Criminal Law. Aurora, Ontario: Canada Law Book, pp. 335-49.

Shearing, C and Wood, J 2003. 'Governing security for common goods', International Journal of the Sociology of Law 31(3): 205-25. doi. org/10.1016/j.ijsl.2003.09.005.

van Sluis, A, Marks, P, Gilleir, F and Easton, M 2012. 'Nodal security in the Ports of Rotterdam and Antwerp', in M Fenger and V Bekkers (eds), Beyond Fragmentation and Interconnectivity: Public Governance and the Search for Connective Capacity. Amsterdam: IOS Press, pp. 73-94.

Wakefield, A 2003. Selling Security. New York: Routledge. 
Wall, D 2007. 'Policing cybercrimes: Situating the public police in networks of security with cyberspace', Police Practice and Research: An International Journal 8(2): 183-205. doi. org/10.1080/15614260701377729.

Weber, M 1946. From Max Weber. HH Gerth and CW Mills, eds. New York: Galaxy.

White, A 2011. 'The new political economy of private security', Theoretical Criminology 16(1): 85-101. doi.org/10.1177/ 1362480611410903.

Wood, J and Dupont, B 2006. 'Introduction: Understanding the governance of security', in J Wood and B Dupont (eds), Democracy, Society and the Governance of Security. Cambridge: Cambridge University Press, pp. 1-10. doi.org/10.1017/ CBO9780511489358.002.

Wood, J and Shearing, C 2007. Imagining Security. London: Willan.

Wright, J and Head, B 2009. 'Reconsidering regulation and governance theory: A learning approach', Law E Policy 31(2): 192-216. doi. org/10.1111/j.1467-9930.2009.00301.x.

Zedner, L 2009. Security: Key Ideas in Criminology Series. New York: Routledge. 
This text is taken from Regulatory Theory: Foundations and applications, edited by Peter Drahos, published 2017 by ANU Press, The Australian National University, Canberra, Australia. 